\title{
ECONOMIC CRISIS AND WAGE DIVERGENCE: EMPIRICAL EVIDENCE FROM ROMANIA
}

\author{
Gheorghe Zaman, Zizi Goschin*
}

\begin{abstract}
:
This paper addresses the question of convergence in real wages across Romanian counties, while putting a spotlight on the recent economic crisis, which has hit hard the entire economy. Following the main methodological trends in the literature, convergence methods were applied using the traditional cross-section approach. The empirical analysis covering a 21-year period provided clear evidence in favour of $\beta$-convergence, but indicated $\sigma$-divergence (Galton's fallacy). Wages' dispersion seems to rise during the economic crises and persists in the first stage of recovery as well. This finding provides support to Barro and Sala-i-Martin's theory on the temporary divergence effect induced by economic shocks.
\end{abstract}

Keywords: sigma and beta convergence, real wage, economic crisis, Romania

JEL Classification: O47, J31, R15

\section{Introduction}

The EU policy states among its major objectives the enlargement of inclusion, solidarity and social cohesion, and the narrowing of social and economic gaps between regions. In this strategic context the income distribution and wage policy, as well as the reduction of poverty have a special importance. Such topics are now attracting renewed interest in the context of the ongoing labour market adjustments and real income decline due to the economic crisis. At the EU level, the crisis appears to have determined a shift from convergence and cohesion towards competitiveness, with mixed spatial effects, depending on the magnitude and severity of the recession in each region.

The real convergence process is a crucial economic issue for the regional development and a long-running theme for empirical research in regional economics. Studies on this topic experienced a great expansion since the early 1990s and generated a vast theoretical and empirical literature. These studies have typically addressed the convergence process from the perspective of GDP per capita (production per capita) and productivity (output per employee or per hour). Without denying the importance of this approach, we follow a distinctive, less frequent, line of research and address the convergence analysis

* Gheorghe Zaman, Institute of National Economy, Romanian Academy of Science, Bucharest, Romania (georghezaman@ien.ro); Zizi Goschin, Bucharest Academy of Economic Studies and Institute of National Economy, Romania (zizi.goschin@csie.ase.ro). 
in terms of real wages. This approach is particularly relevant for the individual wellbeing, since wages can be "a better indicator of economic welfare" for the largest part of the population (Williamson, 1998). As the various indicators used in the convergence analysis, such as GDP per capita, productivity or wages, are interconnected and display common trends, conclusions should be nevertheless similar (Emerson et al., 1992; Mora, 2005). Empirical studies provided evidence that the wage convergence process and GDP are interlinked; for instance, based on a panel estimation of wage elasticity in respect to GDP per capita growth in the four so-called cohesion countries in the EU, namely Greece, Ireland, Portugal and Spain, Gács (2001) reported that following their accession to EU wage convergence accompanied GDP per capita convergence, with a $0.65-0.80 \%$ wage growth for each percent of GDP/capita growth.

In line with the mainstream literature, the convergence topic has been usually addressed in the Romanian empirical research from the GDP per capita perspective (see for instance Iancu, 2007 and Iancu, 2009), while the wage approach has been considered only indirectly and partially. This paper is an attempt to develop a new perspective on real convergence in Romania, based on the territorial inequalities in wages. Moreover, we address this issue in the framework of the economic crisis that brought about a new set of challenges to the labour market, the decline in real wages being one of its most socially negative effects. The crisis may have mixed effects on the wages (O'Farrell, 2010): redundancies of the lower paid workers tend to create a statistical effect of growth in the average wage, even in the absence of real wage increases, but the decreased economic activity reduces the demand for labour, therefore putting downward pressure on wages. Prior to the recent economic crisis, Romania experienced a period of sustained and relatively rapid economic growth that, combined with workforce shortages in some sectors, underpinned significant increases in wages, in particular after the accession to the EU, and fostered the catch-up of the poorer regions. Since the onset of the global economic crisis, that trend has been swiftly disrupted, and even reversed, due to the economic decline in most sectors. Considering, as the theory states, that regional equalization of wages is not possible even under perfect labour market conditions, then challenging questions, concerning both regional wage convergence/divergence trends and the maximum acceptable magnitude or the optimum level of wage disparities in the crisis context, naturally emerge. Only the first question will be addressed in this study.

The contribution of this paper is twofold. On the one hand, it introduces the wage perspective on convergence as a new line of research in Romania. On the other hand, it singles out the impact of economic shocks by analysing the convergence process both prior and during the crisis. What are the forces behind the wage differentials at country level? And how did the convergence process react to the economic crisis? Therse are the two key research questions addressed in this paper. We provide some new empirical evidence on these issues and discuss the implications of the corresponding findings for the regional policy and strategy. 
The rest of the paper proceeds as follows. Section 2 briefly outlines the theoretical background of this research agenda. Section 3 defines the methodology employed in our empirical investigation, based on some well-known tools from the convergence literature; it also presents the variables and the datasets. Section 4 reports the results from our two main lines of research: the sigma convergence indicators and the beta convergence models, while Section 5 concludes by resuming the main findings and their implications in terms of regional policy.

\section{Regional Wage Differentials and Wage Convergence}

The starting point of many theories that address regional inequalities is the role played by production factors' different degrees of mobility in space. Economic theory demonstrates that the mobility of labour and capital tend to narrow the price gaps in local markets, leading towards economic convergence. Empirical evidence supports this theory, but suggests that certain limitations to labour mobility might be induced by the existence of some region-specific factors, such as geography and climate, or differences in rates of urbanization. For instance, the workers' valuation of local characteristics can impact their relocation decisions, therefore acting as an important source of regional inequalities, including wage disparities. Workers in search of employment opportunities, as their prime goal, may also be driven towards a certain region by the pleasant climate, the diversity, the quality and the low prices of local goods and services, the housing facilities, the local traditions, etc. In contrast, high crime rates, pollution, big local taxes, poor services, administrative measures against immigration and a significant risk of unemployment act as rejection factors of a region (Simpson, 2000). Following this line of thought, it can be assumed that the labour market conditions, combined with regional characteristics and the costs associated with moving to the new location are key determinants of workers' mobility. On this basis, there is general agreement that in large cities the workers can find numerous and diverse employment opportunities, but they have to face high housing costs, overcrowding and other drawbacks which need to be compensated by higher wages compared to rural zones (Brown, 1990; Williamson, 1990; Reher, 2001).

Another notable cause of regional wage inequalities is the labour heterogeneity. When choosing a location, the firms take into account both the human capital endowment, in terms of qualification level, experience, training and education, and the cost of labour in different regions. The differences in the human capital of the regions bring about inequalities in their productivity levels, one of the main driving forces behind wage differentials (Maza and Villaverde, 2006). On the other side, workers compare the potential revenue that their education, skills and employment experience can bring in different regions. The locational choices of both companies and workers have direct effect on the territorial variability in wages. Nevertheless, specific company characteristics can also determine much of the variation in wages, independent of location. For instance, Reis (2002) and Roses (1998) reported that wages tend to be greater if the firm is big or has a high level of capital per worker. 
Regional wage variation is also influenced by migration of workers from lower to higher wage regions, thus putting pressure towards regional convergence (Mikelarena, 1993), but this seems to be a more controversial factor. Some empirical studies in the literature have reported limited influence of labour migration on the level of regional wages (e.g. Borjas, 1994). Given that, in the framework outlined by Heckscher-Ohlin theory, trade in goods can substitute migration, convergence is possible irrespective of the spatial movement of labour (O'Rourke and Williamson, 1999).

It is also noteworthy, among the major factors influencing regional wage convergence, phenomena such as crisis and recession in general. For instance, Phillips (1992) found that, alongside educational and occupational factors, specific economic shocks have the potential to increase both national and regional wage inequality. A series of studies, such as Eberts and Stone (1992), have suggested that, although households and firms are mobile and can adjust to economic shocks, the period necessary to adapt may be long (up to 10 years), which may explain the persistence of regional differentials. Addressing the regional wage distributions over time, Monastiriotis (2002) finds evidence that cross-regional wage divergence can be largely explained by territorial variation in the occupational composition of the workforce. Since the crisis impacts differently each sector, it also acts with variable intensity in each region, depending on its specific mix of activities, and brings about structural changes in the workforce that further fuel the regional wage inequalities.

Last but not least, some economic factors may be simultaneously favourable and/or detrimental to spatial wage convergence: innovation (Lee and Pose, 2012), foreign direct investments with vertical and horizontal effects ${ }^{1}$ (Martin, 2005; Jurajda, 2011; Clipa et al., 2012), etc.

Given the complexity of the convergence process, different views have been expressed in the literature and multiple research angles were adopted. While the neoclassical model of growth predicts that convergence necessarily occurs due to diminishing returns of inputs, the endogenous growth theory points to factors such as human capital and technological progress that are not affected by the law of diminishing returns. Such factors maintain the competitive advantage of the developed regions and have a positive effect on productivity and wage. The theories that oppose convergence found empirical support as well. Findings from classical studies such as Barro and Sala-i-Martin (1991) sigma convergence in the USA over 1880-1988 based on per capita income have been contradicted by new empirical research. For instance, Drennan et al. (2004) and Drennan (2005) found evidence of divergence in metropolitan wages in the USA over 1969-2001.

In Romania empirical studies on wage convergence have not been undertaken so far, but many researchers addressed the issue of wage inequalities. The studies on this topic agreed on the relatively low regional and occupational wage disparities at the onset of

1 Horizontal FDI involve a duplication of national products by creating new enterprises that serve the local markets, while vertical FDI in search of low-cost inputs generate activities' relocation and create trade flows. 
the transition to market economy, in the early 1990s, which is considered a result of the centralized wage-setting process, providing only limited returns to skills, during the former communist regime (Brainerd, 2010). The increase in wage inequality that started during the transition years and continued thereafter had been explained in the literature by factors such as the improved quality of the workforce due to sharp increase of enrolments in the higher education after 1989 (Skoufias, 2003). In the same register, Andrén et al. (2005) assessed the wage impact of schooling for Romanian workers, comparing the central planning period to the transition years, and found that the schooling wage premium, which was low under central planning, become more than double by 2000 . Since the early 1990s, wages were set at the firm level, in better accordance to the employees' skills, thus producing a sizeable increase in wage inequality. Increased variation in labour productivity across regions may also explain the higher wage differentials (Goschin, 2007). Border opening and workforce out-migration have reduced the pressure on the domestic labour market, explaining some of the wage increase, especially in the 2000-2007 period. These factors acted with variable intensity across the regions, fuelling higher territorial wage discrepancies.

Starting from these empirical findings in the literature, the present paper addresses the emerging changes in the economic behaviour owing to the crisis that might have long-lasting negative consequences on wages and may impact the wage convergence process.

\section{Methods, Variables and Data}

In the context of the increasing regional wage inequalities in the last two decades, we aim to analyse the territorial wage convergence/divergence phenomenon in Romania, by approaching this issue from the perspective of the economic cycle. More specifically, we aim to assess the likely negative impact that strong economic shocks, such as the recent crisis, may exert on the convergence process. The research methodology used for this purpose combined three investigation perspectives that provided complementary insights into real wage convergence, namely analysis of territorial wage dynamics, sigma convergence coefficients and beta convergence models. The most common choices in the empirical studies on convergence are the so-called sigma $(\sigma)$ and beta $(\beta)$ convergence methods (Barro and Sala-i-Martin, 1991) that envisage the regional growth process based on the analysis of long-term variations in GDP per capita. The "sigma convergence" is defined as a fall in GDP dispersion across regions, while "beta convergence" implies that the poor regions achieve a more rapid economic growth than the rich ones, thus narrowing the territorial development gaps as measured by GDP per capita.

The sigma convergence approach. Sigma convergence occurs if the territorial dispersion of a variable declines over time. In this paper, we measure sigma convergence in real wages with the coefficient of variation, calculated as the standard deviation of wages across counties relative to the average county wage: 


$$
\sigma_{t}=\frac{\sqrt{\frac{\sum_{i=1}^{n}\left(y_{i}-\bar{y}\right)^{2}}{n}}}{\bar{y}}
$$

where $\sigma_{t}$ is the coefficient of variation in year $\mathrm{t}, \boldsymbol{y}_{\boldsymbol{i}}$ stands for the real wage in county $i, \overline{\boldsymbol{y}}$ is the average wage and $\boldsymbol{n}$ the number of counties. The decline in the coefficient of variation over a period of T years $\left(\sigma_{t 0+T}<\sigma_{t 0}\right)$ indicates sigma convergence, while its increase $\left(\sigma_{t 0+T}>\sigma_{t 0}\right)$ is a proof of the divergence process taking place. An alternative measure of sigma convergence (providing similar results) is the standard deviation of the natural logarithm of wages across counties.

The existence of persistent convergence/divergence trend on the long-run can be further tested based on the following regression:

$$
\sigma_{t}=a+b t+\varepsilon_{t},
$$

where $\sigma_{\boldsymbol{t}}$ represents the sigma time series and $\boldsymbol{b} \boldsymbol{t}$ is the trend line. A significant coefficient on the trend variable $\boldsymbol{t}$ indicates convergence when negative and divergence when positive. The previous specification can be further extended, allowing for an autoregressive AR(1) process:

$$
\sigma_{t}=a+b t+\rho \sigma_{t-1}+\varepsilon_{t}
$$

In order to test for the presence of non-stationarity ${ }^{2}$ in the $\sigma$ series, we will use the well-known Augmented Dickey-Fuller (ADF) test (Dickey and Fuller, 1981), as well as the more powerful DF-GLS test (Elliott et al., 1996) that is a variant of ADF based on Generalized Least Squares regression. The ADF unit root test is performed by estimating the following equation obtained by subtracting $\sigma_{t-1}$ from both sides of relation (3):

$$
\Delta \sigma_{t}=a+b t+c \sigma_{t-1}+\varepsilon_{t},
$$

where $\boldsymbol{\Delta} \boldsymbol{\sigma}_{\boldsymbol{t}}$ represents the first difference in sigma values, $\boldsymbol{b} \boldsymbol{t}$ is the trend line, $\boldsymbol{c}=\boldsymbol{\rho}-\boldsymbol{I}$ and the null hypothesis of the ADF test is the presence of the unit root $\left(\mathrm{H}_{0}: c=0=>\right.$ $\boldsymbol{\rho}=1$ ) agains the alternative $\mathrm{H}_{\mathrm{A}}: \boldsymbol{c}<0$. If the unit root hypothesis is rejected, this is considered evidence in favour of the convergence process. The opposite gives support to the divergence hypothesis (Drennan, 2004).

The beta convergence approach. The beta convergence concept is derived from the neoclassical growth model of Solow-Cass-Koopmans (Barro and Sala-i-Martin, 2004) and is based on the decreasing efficiency of capital: if underdeveloped economies grow faster compared to developed ones, it means that there is an inverse relationship between the starting level (GDP per capita at $t_{0}$ ) and GDP growth per capita over

2 A non-stationary sigma time series follows an autoregressive $\operatorname{AR}(1)$ process, with $\rho=1$ indicating a unit root. 
the interval $\boldsymbol{t}_{0}-\boldsymbol{t}_{0+\mathrm{T}}$. Beta convergence is indicated by the negative value of the parameter $\mathrm{b}$ in the following equation of growth:

where:

$$
\frac{1}{T} \log \left(\frac{y_{i, t_{0}+T}}{y_{i, t_{0}}}\right)=a+b \log \left(y_{i, t_{0}}\right)+\varepsilon_{i t},
$$

$\boldsymbol{y}_{i, t 0}$ and $\boldsymbol{y}_{i, t_{0}+\mathrm{T}}$ stand for initial and final level of GDP per capita in region $i$;

$\frac{1}{\boldsymbol{T}} \log \left(\frac{\boldsymbol{y}_{\boldsymbol{i , \boldsymbol { t } _ { 0 } + \boldsymbol { T }}}}{\boldsymbol{y}_{\boldsymbol{i}, \boldsymbol{t}_{0}}}\right) \quad \begin{aligned} & \text { is the GDP per capita annual average growth over the interval } \boldsymbol{t}_{0}-\boldsymbol{t}_{0+\mathrm{T}} \\ & \text { in region } i\end{aligned}$

$\boldsymbol{T}$ - the time span under consideration (the number of years between baseline $\boldsymbol{t}_{0}$ and final moment $\boldsymbol{t}_{0+\mathrm{T}}$ );

$\boldsymbol{a}$ - constant;

$\boldsymbol{b}$ - the regression coefficient;

$\varepsilon_{i t}$-the error.

The beta convergence method tests whether the higher growth rates of poorer regions are behind the convergence process identified using sigma measures. Sigma convergence necessarily implies beta convergence, but the reverse does not necessarily hold; beta convergence may occur without reducing the wage dispersion because the economic shocks affect unevenly both the sectors and the regions and may counter the decline in wage dispersion (Barro and Sala-i-Martin, 1995). Therefore $\beta$-convergence may coexist with constant or even bigger sigma values over time (Galton's fallacy). Sigma divergence is compatible with either beta convergence or divergence (Wodon and Yitzhaki, 2005). Although both sigma and beta method are useful and they provide different but complementary perspectives on convergence (Barro, 1995) in the end only $\sigma$-convergence is able to confirm the decline in disparities (Friedman, 1992; Quah, 1993).

According to the classification developed by Galor (1996), there might be different forms of beta convergence. Absolute (unconditional) $\boldsymbol{\beta}$ convergence disregards the technological or institutional differences across regions (i.e. assumes structural homogeneity) and relies solely on the different starting levels, unconditionally accepting the hypothesis of more rapid growth in the less developed regions. Conditional $\boldsymbol{\beta}$ convergence acknowledges the differences between countries, i.e. the existence of structural heterogeneity. From the methodological perspective, differences between regions are addressed by including in the model explanatory variables that reflect the heterogeneous characteristics of the regions: for the instance the literacy rate as a proxy for human capital and the rate of urbanization as a proxy for physical capital (Roses and Sanchez, 2002), the capital depreciation rate, the population growth and the technological progress (Barro and Sala-i-Martin, 1992; Mankiw et al., 1992). Following the inclusion of the additional variables, conditional $\beta$ convergence could be found in many instances even in the absence of absolute convergence. 
The general models of beta convergence can be adjusted and further employed for the analysis of wages, as wage convergence usually accompanies the GDP per capita convergence (real convergence), the two processes being naturally interrelated. Beta convergence in regional wages is present if lower wages grow faster than the higher ones. This convergence process may occur unconditionally or not. In line with Barro and Sala-i-Martin (1995), we first consider the basic regression model of absolute (unconditional) convergence by employing the initial wage as the only explanatory variable for regional wage growth:

$$
\frac{1}{T} \ln \left(\frac{W_{i, t_{0}+T}}{W_{i, t_{0}}}\right)=a+b \ln \left(w_{i, t 0}\right)+\varepsilon_{i t},
$$

where:

$\boldsymbol{W}_{i, t o}$ and $\boldsymbol{W}_{i, t o+T}$ are the initial and final level of real wage in the county $i$;

$\frac{1}{\boldsymbol{T}} \ln \left(\frac{\boldsymbol{W}_{\boldsymbol{i}, \boldsymbol{t}_{0}+\boldsymbol{T}}}{\boldsymbol{W}_{\boldsymbol{i}, \boldsymbol{t}_{0}}}\right) \begin{aligned} & \text { is the average annual growth in real wage in the county } i \text { during the } \mathrm{T} \\ & \text { year period under consideration; }\end{aligned}$ $\boldsymbol{a}$ is constant;

$\boldsymbol{b}$ is the regression coefficient;

$\varepsilon_{i t}$ is the error (with the usual properties).

The $\boldsymbol{\beta}$ convergence rate, representing the pace at which the economy is approaching the steady state, is computed with the following formula (Barro and Sala-i-Martin, 1995):

$$
\beta=-\frac{\ln (1+b \times T)}{T} .
$$

It is indicating the speed of convergence, specifically the annual rate at which lower regional wages are approaching the higher ones.

The second model that we are going to use is taking into account that the economic differences between regions translate into different steady-state levels, which influence the convergence process as well. According to Barro and Sala-i-Martin (1995), the bigger the distance to the steady-state position, the faster the rise in wages. For the conditional convergence regression model, additional control variables have to be included:

$$
\frac{1}{T} \ln \left(\frac{W_{i, t_{0}+T}}{W_{i, t_{0}}}\right)=a+b \ln \left(W_{i, t_{0}}\right)+\sum_{j} c_{j} \ln \left(X_{i j, t_{0}}\right)+\varepsilon_{i t}
$$

The additional variables $\boldsymbol{X}_{\boldsymbol{j}}$ entered in the model (Table 1) capture the economic differences between counties in terms of indicators that may have a influence on wages. The GDP per capita is an important measure of the county's wealth, in direct connection to the wages, while annual gross investments, as well as the stock of foreign direct investments are important sources for job creation and wage increase. In Romania, 
the wages are usually much higher in the companies that hold foreign capital. The education, as a proxy for human capital, is also expected to have a positive impact on wage growth.

The unemployment rate captures the degree of unbalance on the labour market, which in turn affects wages. Unemployment not only diminishes the incomes of those directly affected, but "over time puts a downward pressure on the wages of those still in employment" (O'Farrel, 2010). Economic theory suggests that a wage-unemployment trade-off might take place during a crisis and recent statistical data confirm a far stronger drop in employment (hence increasing unemployment), compared to wages. On the average, the unemployment rate has doubled in Romania over 2009-2010, while in some counties it became more than triple.

Finally, emigration and immigration rates are used as proxies for workforce migration, another factor that influence the labour market equilibrium and the wages. If migration is an important source of wage convergence, as many economists consider (see for instance Barro and Sala-i-Martin, 1995), the estimated convergence coefficient should change when the migration takes place constantly. All additional variables are considered at their initial levels (at $\mathrm{t}_{0}$ ) and have been computed as natural logarithms of the original values.

The basic models of wage dispersion reflect the degree in which regional differences are modified by the territorial level of analysis, usually by increasing the gap when analysing smaller areas (for instance, counties rather than regions). Consequently, this paper uses the 41 counties of Romania, plus the Bucharest Municipality, the lowest territorial level for which official statistical data on the variables of interest are available. The data for all but one variable came from the National Institute of Statistics online database (TEMPO online). The indicators have been calculated in real terms by deflating nominal wages by the annual consumer price index and GDP by annual GDP price index. In order to increase comparability, whenever possible the variables were computed in per capita or per 1,000 inhabitants form. Finally, all variables for the beta convergence models were transformed as natural logarithms from the original data.

Before moving on to the regression analysis of the data, it is useful to investigate whether the variables are significantly different across Romanian counties. The descriptive statistics used for this purpose pointed to sufficient variation for further testing the association between the control variables and wage growth. 
Table 1

The Variables in the Beta Convergence Models

\begin{tabular}{|c|c|c|}
\hline Variable & Description*) & Data source \\
\hline $\begin{array}{l}\text { Real wage } \\
\text { growth }\end{array}$ & $\begin{array}{l}\text { Average annual percentage growth in real } \\
\text { wage (dependent variable) }\end{array}$ & $\begin{array}{l}\text { Romanian Institute of National } \\
\text { Statistics (INS) database and own } \\
\text { computations }\end{array}$ \\
\hline Wage & $\begin{array}{l}\text { Monthly average net earnings (wages and } \\
\text { other labour income) in the year of reference, } \\
\text { at county level, in RON }\end{array}$ & INS \\
\hline GDP/capita & $\begin{array}{l}\text { The annual Gross Domestic Product per } \\
\text { capita, measured in RON/inhabitant }\end{array}$ & INS and own computations \\
\hline $\begin{array}{l}\text { Gross } \\
\text { investments/ } \\
\text { capita }\end{array}$ & $\begin{array}{l}\text { Total annual gross investments in } \\
\text { non-agricultural sectors, in RON/inhabitant }\end{array}$ & INS and own computations \\
\hline $\begin{array}{l}\text { FDI stock / } \\
\text { capita }\end{array}$ & $\begin{array}{l}\text { The foreign direct investments stock from } \\
1991 \text { to the year of reference, measured in } \\
\text { RON/inhabitant }\end{array}$ & $\begin{array}{l}\text { Romanian Chamber of Commerce } \\
\text { and Industry and own computations }\end{array}$ \\
\hline Education & $\begin{array}{l}\text { The number of tertiary education graduates } \\
\text { per } 1,000 \text { inhabitants }\end{array}$ & INS and own computations \\
\hline $\begin{array}{l}\text { Emigration } \\
\text { rate }\end{array}$ & $\begin{array}{l}\text { The emigration rate represents the persons } \\
\text { that are permanently changing their residence, } \\
\text { moving from the county of reference either } \\
\text { to another county (internal migration) } \\
\text { or another country (external migration). } \\
\text { It is measured as number of emigrants } \\
\text { per } 1,000 \text { inhabitants of the county of origin. }\end{array}$ & INS and own computations \\
\hline $\begin{array}{l}\text { Immigration } \\
\text { rate }\end{array}$ & $\begin{array}{l}\text { The emigration rate refers to the persons } \\
\text { that are permanently moving their residence } \\
\text { into a county. They may come from another } \\
\text { county (internal migration) or another country } \\
\text { (external migration). It is measured as number } \\
\text { of immigrants per } 1,000 \text { inhabitants of the } \\
\text { destination county. }\end{array}$ & INS and own computations \\
\hline $\begin{array}{l}\text { Unemployment } \\
\text { rate }\end{array}$ & The percent of unemployed & INS \\
\hline
\end{tabular}

*) All variables are measured at county level.

\section{Results}

As previously mentioned, there was a significant increase in wage inequalities in Romania during the transition to the market economy as well as during the sustained economic growth period 2000-2008. Our aim is to investigate the territorial variation in real wages on the long-run and to single out the changes in convergence/divergence pattern associated with economic crises. 


\subsection{Sigma divergence}

Annual calculations made for the period 1991-2011 show that the coefficient of wage variation had an upwards trend reaching a first peak of $12.43 \%$ in 2001 , followed by a short period of decline over 2002-2004 and then continuous growth with a second peak at 14.63\% in 2011 (Figure 1). The coefficient of wage variation between Romanian counties has significantly fallen down only in a period of strong economic growth and big increase in wages. Although the sigma value generally had a small range of variation, lying between $10 \%$ and $12 \%$ from 1993 to 2009 , it is noticeable that the shocks of economic crises, in the early and late 1990s and the recent 2009-2010 crisis, had sizeable, rapid and lasting effects towards increasing sigma divergence.

When compared with empirical studies undertaken for other countries Romanian figures may be considered moderate. Studies based on European data reported sigma coefficients for real wage varying from a minimum of $14 \%$ for industrial workers in Spain (Roses, 2004 ) and $15 \%$ for agricultural workers in the Great Britain, to a maximum of $20 \%$ for unskilled workers in Sweden (Boyer and Hatton, 1994). In Romania, the biggest values in sigma correspond to industry and constructions, where the coefficient of variation went up to $21.46 \%$ in 2010 .

As regards the causes behind the increases in wage dispersion over 1991-2011, we can point to a few significant factors:

- Romania had relatively stable and low national unemployment rates, but there are large and persistent differences in the regional unemployment rates; the territorially unbalanced unemployment and the increased low-wage employment acted as major factors in the growth of income inequality and poverty across the regions; it is worth mentioning that significant and persistent income gaps separate the capital city Bucharest from the rest of the country;

- as in other East European countries, in the early years of transition the minimum wage fell relative to the average wage; although it has stabilized now, this may explain some of the previous increase in wage inequality;

- border opening and workforce out-migration have reduced the pressure on the domestic labour market, explaining some of the wage increase, especially in the 2000-2008 period; since these factors acted with variable intensity across the regions, higher territorial wage discrepancies emerged;

- the territorially uneven increases in human capital based on higher enrolments in the tertiary education in the last two decades fuelled production and wage inequalities. 
Figure 1

Sigma Divergence in Wage for Romanian Counties over 1991-2011

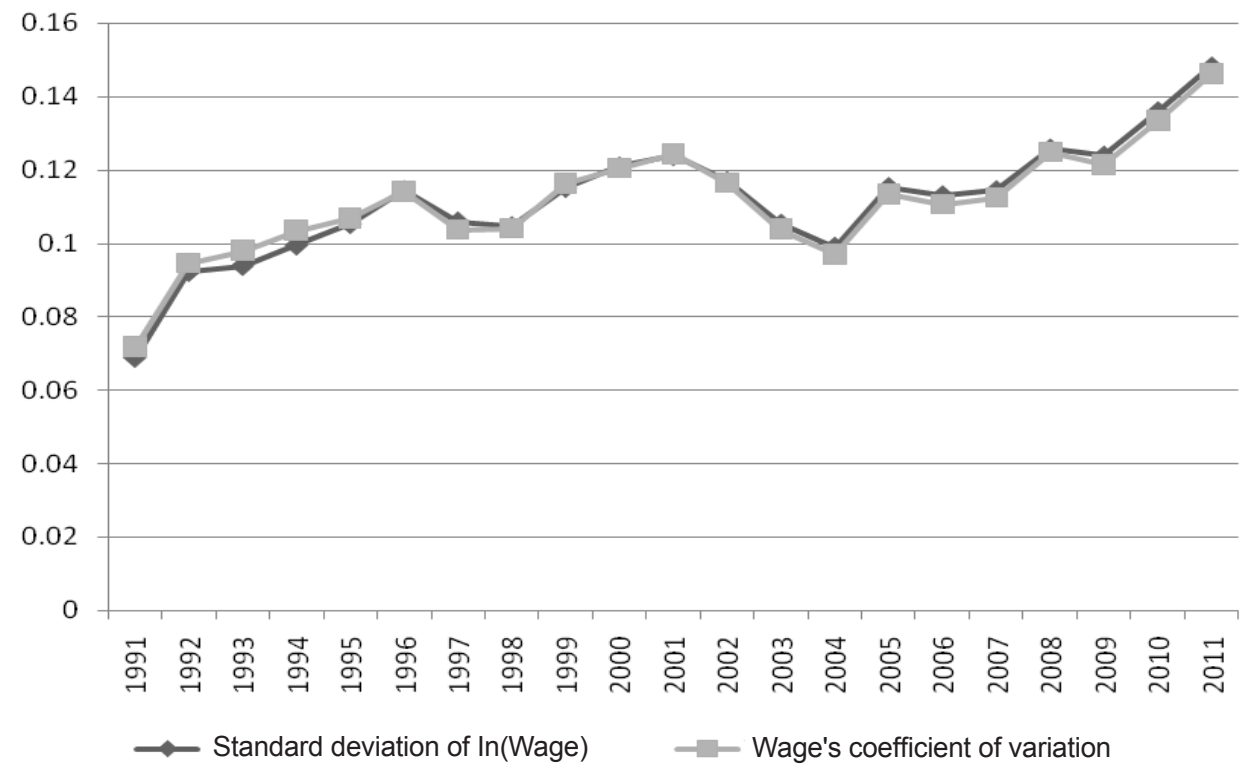

In order to test sigma divergence indicated by the previous results we further estimated the sigma trend equation in (2). The results presented in Table 2 show a positive and highly significant trend coefficient that supports the divergence hypothesis (rising wage dispersion trend).

Table 2

Results from the Sigma Trend Regression 1991-2011

\begin{tabular}{|l|c|c|}
\hline Variable/statistic & Coefficient & Std. Error \\
\hline Constant & $0.087854^{* * *}$ & 0.004664 \\
\hline Trend & $0.002154^{* * *}$ & 0.000371 \\
\hline R-Squared & \multicolumn{2}{|c|}{0.638995} \\
\hline F statistic & \multicolumn{2}{|c|}{$33.63090^{\star * *}$} \\
\hline
\end{tabular}

Significance: ${ }^{* * *} p<0.01$

Source: authors' own calculations.

Results from sigma trend equation (3), including an autoregressive AR(1) process (Table 3) also indicate a positive, although less significant trend coefficient. The coefficient on lagged sigma is negative and highly significant. 
Table 3

Results from the Augmented Dickey-Fuller Test Equation 1991-2011 (dependent variable $\Delta \sigma$ )

\begin{tabular}{|c|c|c|}
\hline Variable/statistic & Coefficient & Std. Error \\
\hline Sigma (-1) & $-0.517635^{\star \star *}$ & 0.189687 \\
\hline Constant & $0.051372^{\star * \star}$ & 0.017390 \\
\hline Trend & $0.000895^{\star}$ & 0.000476 \\
\hline R-Squared & \multicolumn{2}{|c|}{0.307426} \\
\hline F statistic & \multicolumn{2}{|c|}{$3.773052^{\star *}$} \\
\hline
\end{tabular}

Significance: ${ }^{* * *} p<0.01 ;{ }^{* *} p<0.05 ;{ }^{*} p<0.1$

Source: authors' own calculations.

As indicated by the test statistics in Table 4 both the Augmented Dickey-Fuller and DF-GLS unit root tests on standard deviation of the natural logarithm of wage fail to reject the null hypothesis of unit root. This implies that sigma time series might follow a random walk with positive drift and trend, therefore contradicting sigma convergence.

Table 4

Statistics from ADF and DF-GLS Unit Root Tests (with intercept and linear trend)

\begin{tabular}{|l|c|c|c|}
\hline \multicolumn{2}{|c|}{} & t-Statistic & Prob. $^{1}$ \\
\hline \multirow{3}{*}{ Tugmented Dickey-Fuller test statistic } & $\mathbf{- 2 . 7 2 8 8 8 3}$ & 0.2365 \\
\hline \multirow{3}{*}{ Elliott-Rothenberg-Stock DF-GLS test statistic ${ }^{2)}$} & $1 \%$ level & -4.498307 & \\
\hline \multirow{3}{*}{ Test critical values: } & $5 \%$ level & -3.658446 & \\
\cline { 2 - 4 } & $10 \%$ level & -3.268973 & \\
\cline { 2 - 4 } & $1 \%$ level & $-\mathbf{- 2 . 4 8 9 0 0 4}$ & \\
\cline { 2 - 4 } & $5 \%$ level & -3.770000 & \\
\cline { 2 - 4 } & $10 \%$ level & -2.890000 & \\
\hline
\end{tabular}

1) MacKinnon (1996) one-sided p-values.

2) DF-GLS test critical values are calculated for 50 observations and may not be accurate for our sample of 20.

Source: authors' own calculations.

To conclude, empirical evidence appears to support sigma divergence in wages among Romanian counties over 1991-2011. Although the neoclassical model of growth predicts that economic shocks will raise temporarily the sigma values but convergence will prevail on the long-run, empirical evidence contradicts this assumption. The Romanian case seems to be in better accordance with the endogenous growth theories that support the hypothesis of persistent divergence. 


\subsection{Beta convergence}

Moving on with the convergence analysis, we further implemented both absolute and conditional convergence models covering the period 1991-2011, subdivided into three sub-periods with opposite GDP and real wage trends (Appendix 1) and bearing markedly different macroeconomic characteristics:

1. the period 1991-1999 represented the transition from the centralised socialist regime to the market economy and was marked by economic and social turmoil, as well as two economic crises (in early and late 1990s), separated by a short recovery; during this period real wages had been on a step downward trend, except for the short period of macroeconomic growth 1995-1996;

2. 2000 to 2008 was a period of sustained economic growth accompanied by a strong rise in real wages;

3. from Q4 2008 to the end of 2010 Romanian economy was affected by a severe economic crisis, followed by a frail recovery ${ }^{3}$ in 2011 and 2012. The crisis had strong repercussions, 2009 and 2010 bringing GDP contractions of $-7.1 \%$ and $-2.1 \%$, respectively. The anti-crisis measures taken by the Romanian government, such as the $25 \%$ reduction in public sector salaries, other direct and indirect tax measures aiming to reduce revenues, as well as the labour redundancies in administration, have resulted in a serious disruption to the wage increases in the previous period.

Given the macroeconomic evolutions, the corresponding wage trends and the previous results on sigma divergence, we consider that applying beta regressions on each sub-period could help highlight the effects of economic crises on wage variation. This could be especially relevant for the last interval, as the recent economic crisis has had a strong impact, but displayed large variation across Romanian regions, and is likely to have influenced the territorial wage convergence/ divergence process as well.

Absolute beta convergence. The simple regression model in (6) tackles the absolute (unconditional) $\boldsymbol{\beta}$ convergence (without controlling for regional-specific differences) in real wages among Romanian counties. This model has produced the results shown in Table 5, for different periods of time.

Beta convergence in real wages is indicated by the negative correlation between the relative growth in real wages and their initial levels. This link can be interpreted based on the sign and the magnitude of the parameter $b$ in the model. The coefficient $b$ estimated for the equation (6) - absolute convergence - is insignificant for the first period 1991-2000, therefore there is no evidence for beta convergence. The coefficient $b$ is negative and statistically significant over the period 2000-2008, as well as for 2000-2011, which confirms beta convergence in real wages (Table 5). The $\beta$ convergence rate, obtained from the relation (7), reached $2.05 \%$ annually over $2000-2008$, the period of sustained economic growth and strong increase in wages, and it was slightly lower over 2000-2011.

3 Nevertheless experts estimate that a return to recession is still possible. 
Table 5

Results from the Absolute Convergence Models

\begin{tabular}{|c|c|c|c|c|c|}
\hline \multirow{2}{*}{ Coefficient/ Statistic } & \multicolumn{5}{|c|}{ Period } \\
\hline & $1991-2000^{a)}$ & $\left.2000-2008^{b}\right)$ & 2008-2011') & 2000-2011b) & 1991-2011 \\
\hline $\begin{array}{l}\text { Coefficient b } \\
\text { (standard error) }\end{array}$ & $\begin{array}{c}0.018661 \\
(0.024958)\end{array}$ & $\begin{array}{l}-0.018941^{*} \\
(0.010247)\end{array}$ & $\begin{array}{c}0.04522^{* * *} \\
(0.01649)\end{array}$ & $\begin{array}{c}-0.01766^{\star \star *} \\
(0.00686)\end{array}$ & $\begin{array}{c}-0.008507 \\
(0.016570)\end{array}$ \\
\hline R-Squared & 0.013784 & 0.078705 & 0.158125 & 0.141886 & 0.0065 \\
\hline F-Stat. & 0.559075 & 3.417148 & 7.512996 & 6.613869 & 0.2636 \\
\hline Durbin-Watson Stat.c) & 2.03182 & 1.99037 & 1.97404 & 1.77073 & 1.89904 \\
\hline Convergence rate $\beta$ & - & 0.02054 & -0.0424 & 0.01964 & - \\
\hline
\end{tabular}

Significance: ${ }^{* * *} p<0.01 ;{ }^{* *} p<0.05 ;{ }^{*} p<0.10$

a) OLS regression; ${ }^{b}$ WLS regression

${ }^{c}$ critical values: $d_{0}=1.48, d_{1}=1.54$

Source: authors' own calculations.

When we single out the period 2008-2011 a positive and highly significant coefficient $\boldsymbol{b}$ is obtained, indicating beta divergence in real wages and the corresponding divergence speed is high: $-4.24 \%$. Such a powerful disruption of the convergence path should be largely if not entirely attributed to the economic crisis that could determine the shift from convergence to divergence in real wages because the contraction in external and domestic demand and the severe drop of domestic and foreign investments brought about a decline in the overall economic activity, producing negative, but spatially different effects on real wages. This result supports Barro and Sala-i-Martin (1995) theory regarding the divergence trend that is induced by external shocks (e.g. the two world wars).

The main factor behind the crisis-led regional divergence in wages in Romania might be struc-tural differences in counties' economies. The effects of the crisis were extremely severe for certain economic activities in particular (for instance, some branches of manufacturing industry, constructions, and real estate transactions) and the counties relying heavily on such industries were hit harder. Given that industries are not uniformly distributed across the country, the decline in economic activity and the corresponding drop in employment and wages had been stronger in some regions than in others, provoking wage divergence.

Conditional beta convergence. The multiple regression model in (8) includes additional variables that may influence the real wage dynamics. The Gross Domestic Product per capita, the stock of FDIs, annual gross investments, migration rates, education and the unemployment rate help capture the economic differences between counties.

The results from the conditional $\beta$ convergence models (Table 6) are confirming the findings from the absolute convergence models, except for the crisis period 2008-2011. From the conditional convergence perspective beta convergence continued despite the crisis, as the estimated $\boldsymbol{b}$ coefficient is negative and significant. The only effect of the crisis seems to be the slowing down of the convergence speed, as the $\beta$ 
rate decreases from $5.42 \%$ over $2000-2008$ to $4.05 \%$ over $2008-2011$. All estimates of the $\boldsymbol{b}$ coefficients in the conditional models are much higher than the corresponding coefficients in the absolute convergence models and the $\beta$ speed of divergence rises accordingly. The high distance between the levels of the $\boldsymbol{b}$ coefficients from the two models points to the existence of important differences separating the counties, which indicate that the counties have indeed different steady-state levels, in line with local conditions. This in turn affects the convergence process.

These $\beta$ values are in line with the findings from empirical studies in other countries. The literature shows a large variability in the size of the wage convergence rate: for the regions of Europe, Barro and Sala-i-Martin (1991) estimated beta values between a minimum of $1 \%$ annually in the $1980 \mathrm{~s}$ and a maximum of $2.3 \%$ annually in the $1960 \mathrm{~s}$, while the estimates made by for U.S. personal incomes (Barro and Sala-i-Martin, 1995) ranged between $1 \%$ and $4 \%$ annually, for different time spans. Williamson (1996) reported estimates ranging between 0.8 and 1.2\% annually. For Spain, Roses and Sanchez (2002) found values between $1.7 \%$ and $8 \%$, while Maza and Villaverde (2006) computed beta values of about $4 \%$.

As expected, regional GDP per capita, FDIs and gross investments per capita are highly significant and have positive influence on the wage dynamics, while the unemployment rate has a negative impact. For the unemployment rate the level of statistical significance is low. The emigration and immigration rate variables are highly significant in all conditional beta regressions. Internal and external migration, as key components of labour mobility, are expected to have a direct impact on wages. The external migration of the Romanian workforce reached high levels in the 2000s, especially prior to the crisis, affecting the domestic labour market equilibrium and explaining, at least partially, the strong increase in wages. The unexpected finding, however, is the sign of the corresponding coefficients. In all regressions, the emigration rate coefficient bears a negative sign, while the immigration rate coefficient bears a positive sign. A plausible explanation is that a large part of the Romanian emigrants are young and educated and are driven out of their counties of origin by better work and business opportunities, with positive wage differentials as a main factor of attraction. This is especially the case of external (international) migration (Roman and Goschin, 2012). It is also true that rich regions in the country attract above average human capital and the associated brain drain decreases productivity and wages in their (presumably) poorer counties of origin, while generating increases in productivity and wage, hence the positive influence on the growth rate of wages, in the destination county. 
Table 6

Results from the Conditional Convergence Models

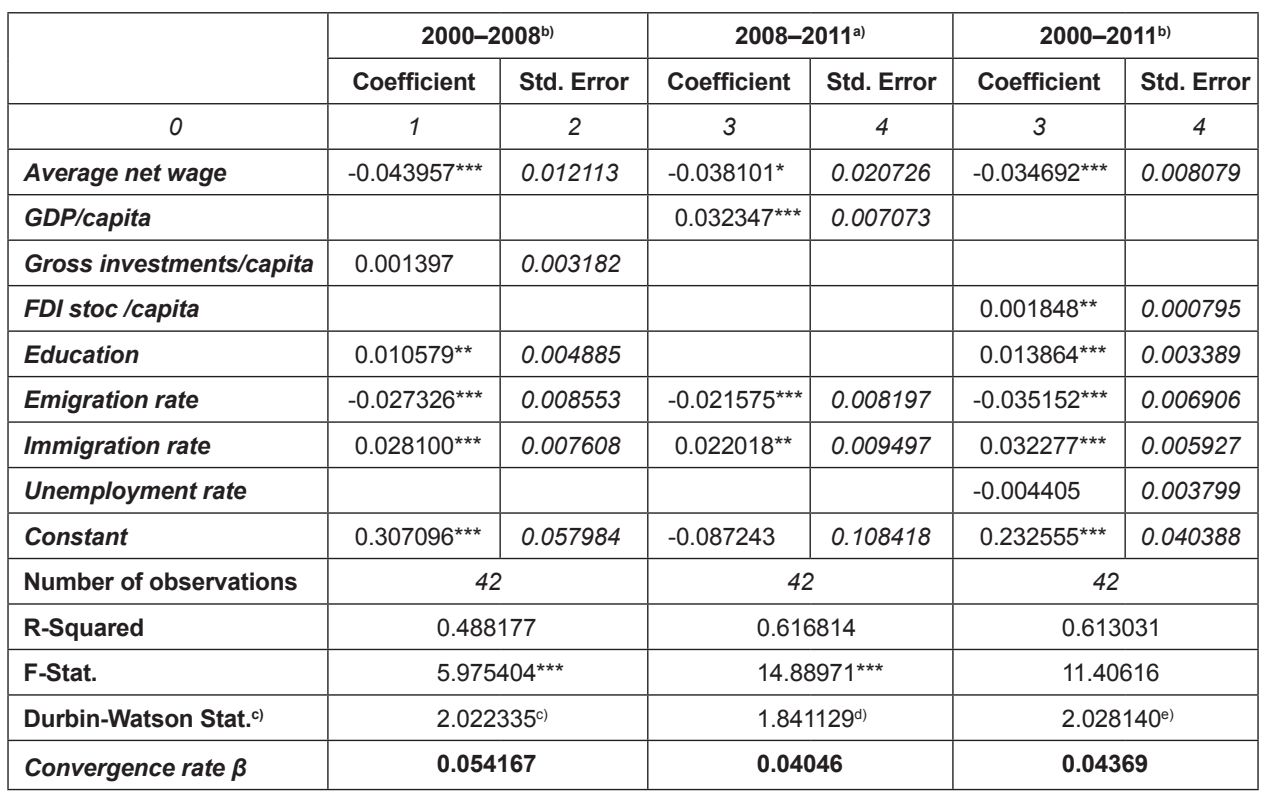

Significance: ${ }^{* * *} p<0.01 ;{ }^{* *} p<0.05 ;{ }^{*} p<0.10$

a) OLS regression; $\left.{ }^{b}\right)$ WLS regression

${ }^{c}$ critical values: $d_{0}=1.23, d_{1}=1.79$; ${ }^{d}$ critical values: $d_{0}=1.29, d_{1}=1.72$; e) critical values: $d_{0}=1.18, d_{1}=1.85$;

Source: authors' own calculations.

Both absolute and conditional convergence models are statistically significant overall; they explain a good proportion of the variability in the wages across counties and autocorrelation of errors is not present (see the statistics in Tables 5 and 6).

In unreported regressions we have also analysed beta convergence in industry during the economic crisis. The results of both absolute and conditional convergence models indicated the manifestation of a process of divergence in regional wages in the industry, but most of the estimations had low statistical significance.

To conclude, there were important differences in the reaction of the Romanian counties to the crisis, according to their economic structure and performance, and consequently both sigma and beta methods recorded significant changes compared to the previous period, as predicted by Barro and Sala-i-Martin (1995).

\section{Summary and Directions for Future Research}

This paper addressed the processes of convergence and divergence in real wages across Romanian counties covering the 1991-2011 period, further subdivided in three sub-periods having different characteristics, and aimed at highlighting the impact of the recent economic crisis. The empirical analysis provided clear evidence in favour 
of $\beta$-convergence, but indicated $\sigma$-divergence (Galton's fallacy). The sigma values and tests pointed to divergence rather than convergence over 1991-2011, although two short sub-periods of convergence occurred during the strong economic growth periods. The unit root tests showed that sigma time series follow a random walk with positive drift, therefore temporary shocks such as the economic crises tend to have long-lasting effects and convergence is unlikely.

The analysis based on classical cross-sectional regressions revealed the existence of both absolute and conditional beta convergence in real wages over 2000-2008, with a relatively high rate of beta convergence, especially in its conditional form. The period from Q4 2008 to 2011 was strongly affected by the economic crisis and the absolute beta convergence process reversed, practically shifting to a "divergence" in wages, while the conditional beta convergence was sizeably slowed down. It should be also noted that the crisis had rapid and powerful effects, bringing about significant wage decline and increased inequalities in a relatively short time. These findings support the literature that states the counter-convergence impact of external shocks, such as the recent economic crisis. Although $\beta$-convergence should tend to generate sigma convergence it seems that in Romania it has been outweighed by stronger opposite factors and sigma divergence persisted over the whole period investigated. This contradicts the assumption of the neoclassical model of growth that convergence across the regions of a country is a natural phenomenon that will prevail on the long-run despite the shocks. We should nevertheless note that the period under consideration is relatively short in terms of convergence process analysis.

The conditional beta regressions showed that the wage growth is positively related to the differences in the level of development of the counties, gross investments and FDIs. Human capital, as well as internal and international and migration, also play major roles. On the other hand, unemployment rates are insignificant as determinants of wage growth, which implies that the degree of spatial wage flexibility in Romania is quite low. The county unemployment rate should play a more active role in the variation of wages, in order to correct the current imbalances in the labour market. In this regard, it is important to note that both market factors and those related to public policy are acting on the income disparities. The existence of a dysfunction between the two groups of factors has a special significance because governments can counter the market-led increased inequality by mechanisms addressing income tax and allowances. Such instruments may however be less effective on long-term because the redistribution is limited in the context of increasing pressure of other public expenditures.

This study represents a necessary first step in the analysis of the implications of the recent crisis on economic convergence and provides potential directions for future research. The analysis can be extended by including more explanatory variables in the conditional convergence equation in order to get a better imagine of regional differences that may influence wage growth. For instance, since the crisis-led decline in production and wage varies from one sector to another, additional variables that capture the sectoral structure of the counties would add significant value to the analysis. From a methodological point 
of view, our future research can be refined by using a panel approach or by applying spatial regression tools that will allow us to account for the neighbourhood influences, as regional differences in wages may act as a pull factor for internal migration of Romanian employees.

\section{Appendix}

Wage and GDP dynamics in Romania, 1990-2011

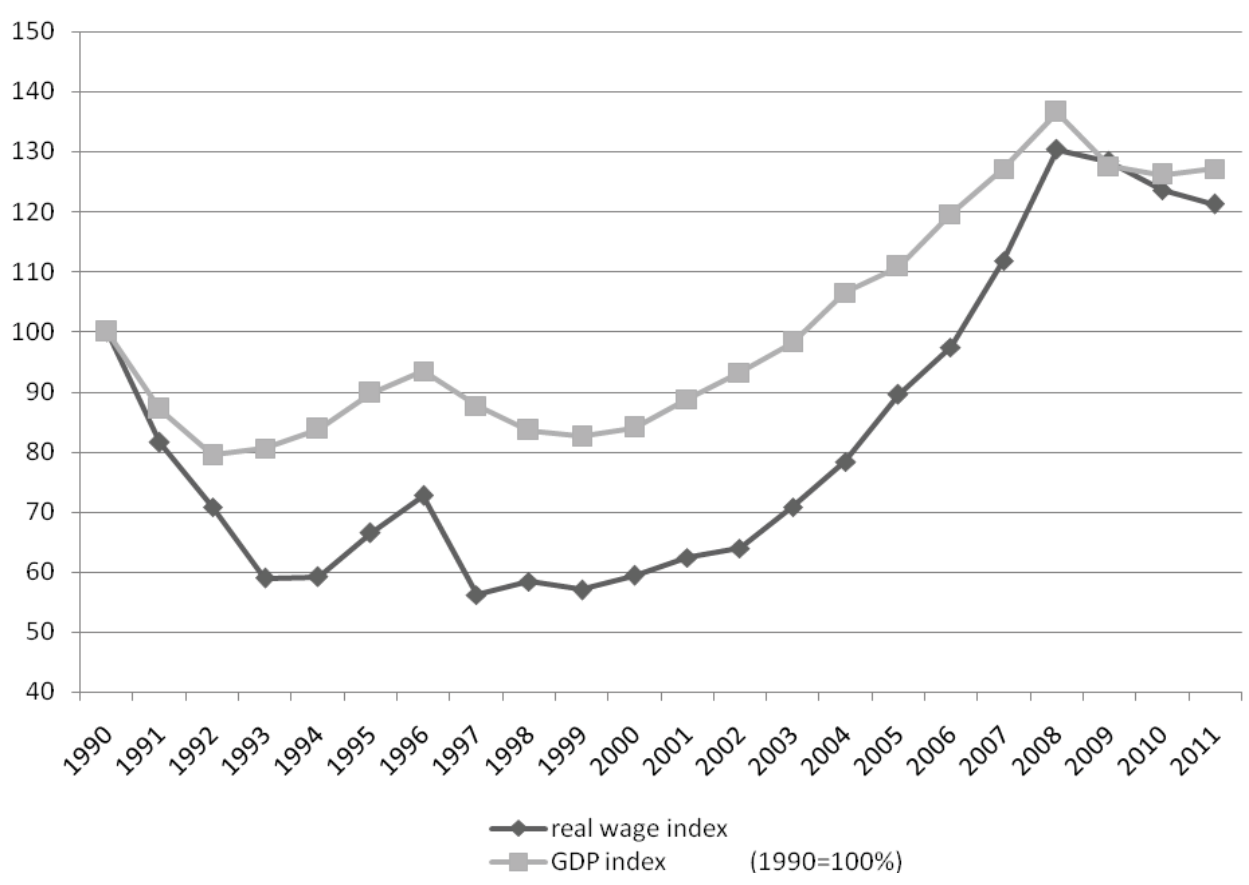

\section{References}

Andrén, D., Earle, J. S., Săpătoru, D. (2005), "The Wage Effects of Schooling under Socialism and in Transition: Evidence from Romania, 1950-2000." Journal of Comparative Economics, Vol. 33, No. 2, pp. 300-323.

Barro, R. J., Sala- i-Martin, X. (1991), "Convergence across States and Regions." Brooking Papers on Economic Activity, Vol. 22, No. 1, pp. 107-158.

Barro, R. J., Sala- i-Martin, X. (1995), Economic Growth. New York: McGraw-Hill.

Barro, R. J., Sala-i-Martin, X. (2004), Economic growth. 2nd ed., Cambridge: MIT.

Borjas, G. J. (1994), "The Economics of Immigration.” Journal of Economic Literature, Vol. 32, No. 4, pp. 1667-1717.

Boyer, G., Hatton, T. J. (1994), "Regional Labour Market Integration in England and Wales, 1850-1913." in Grantham, G. and MacKinnon, M. (eds), Labour Market Evolution, London and New York: Routledge, pp. 84-106. 
Brainerd, E. (2010), "Human Development in Eastern Europe and the CIS since 1990." Human Development Reports Research Paper, http://hdr.undp.org/en/reports/global/hdr2010/papers/ HDRP_2010_16.pdf.

Brown, J. C. (1990), "The Condition of England and the Standard of Living: Cotton Textiles in the Northwest, 1806-1850." Journal of Economic History, Vol. 50, No. 3, pp. 591-614.

Clipa, R. I., Pohoaţă, I., Clipa, F. (2012), "The New Economic Geography and Regional Policy in Romania." Theoretical and Applied Economics, Vol. 19, No.8 (873), pp. 5-18.

Collins, W. (1999), "Labor Mobility, Market Integration, and Wage Convergence in Late $19^{\text {th }}$ century India." Explorations in Economic History, Vol. 36, No. 3, pp. 246-277.

Dickey, D. A., Fuller, W. A. (1981), "Likelihood Ratio Statistics for Autoregressive Time Series with a Unit Root." Econometrica, Vol. 49, No. 4, pp. 1057-1072.

Elliott, G., Rothenberg, T. J., Stock, J. H. (1996), "Efficient Tests for an Autoregressive Unit Root." Econometrica, Vol. 64, No. 4, pp. 813-836.

Drennan, M. P., Lobo, J., Strumsky, D. (2004), "Unit Root Tests of Sigma Convergence across US Metropolitan Areas." Journal of Economic Geography, Vol. 4, No. 5, pp. 583-595.

Drennan, M. P. (2005), "Possible Sources of Wage Divergence among Metropolitan Areas of the United States." Urban Studies, Vol. 42, No. 9, pp. 1609-1620.

Eberts, R. W., Stone, J. A. (1992), Wage and Employment Adjustment in Local Labor Markets. Kalamazoo, Mich.: W. E. Upjohn Institute for Employment Research.

Emerson, M., Gros, D., Italianer, A., Pisani-Ferry, J., Reichenbach, H. (1992), One Market, One Money. Oxford: Oxford University Press.

Friedman, M. (1992), “Do Old Fallacies Ever Die?” Journal of Economics Literature, Vol. 30, No. 4, pp. 2129-2132.

Galor O. (1996), "Convergence? Inferences from Theoretical Models." The Economic Journal, Vol. 106, No. 437 , pp. 1056-1069.

Gács, J. (2001), "Wage Convergence before and after the EU Accession: Economic Foundations, International Experience and Possible Scenarios for Hungary." presentation at Oesterreichische Nationalbank, Austria, available at: http://www.iiasa.ac.at/Research/ETI/docs/whats-new/ wage-convergence.pdf.

Goschin, Z., Constantin D. L. (2010). "The Geography of the Financial Crisis and Policy Response in Romania." Chapter 12 in G. Gorzelak and Ch. Goh (eds), "Financial Crisis in Central and Eastern Europe - from Similarity to Diversity", Warzaw: Barbara Budrich Publishers, pp. 161-190.

Goschin, Z. (2007), "Spatial and Sectoral Analysis of Productivity-Wage Dissimilarities in Romania." Romanian Journal of Regional Science, Vol. 1, No. 1, pp. 33-44.

Quah, D. T. (1993), "Galtonís Fallacy and the Convergence Hypothesis." Scandinavian Journal of Economics, Vol. 95, No. 4, pp. 427-443.

lancu, A. (2007), "Tipurile de convergenţă; convergenta economică." INCE Working Papers, Bucharest. http://convergenta.ince.ro/.

lancu, A. (2009), Convergenţa economică. Bucharest: Editura Academiei Române.

Flam, H., Flanders, M. J. (1991), Heckscher-Ohlin Trade Theory. Cambridge, Mass.: MIT Press.

Jurajda, S. (2011), Regional Divergence and Return to Schooling, Innodrive Project Financed by $7^{\text {th }}$ Framework Programme No. 214576, CERGE-El, Charles University Prague, Czech Republic.

Lee, N., Rodriguez-Pose, A. (2012), "Innovation and Spatial Inequality in Europe and USA." Journal of Economic Geography, Vol. 12, No. 5, pp. 1-22.

Maza, A., Villaverde, J. (2006), "A Territorial Analysis of Wage Convergence/Differentials in Spain." Revue d'Économie Régionale et Urbaine, Vol. 0, No. 4, pp. 615-630.

Martin, R. (2005), A Study of Factors of Regional Competitiveness. A draft final report for the European Commission, Directorate General Regional Policy. 
Monastiriotis, V. (2002), "Inter- and Intra-Regional Wage Inequalities in the UK: Sources and Evolution." LSE Research Papers in Environmental and Spatial Analysis, 70, Department of Geography and Environment, London School of Economics and Political Science, London, UK.

Mora, J., López-Tamayo, J., Suriñach, J. (2005), "Are Wages and Productivity Converging Simultaneously in Euro-Area Countries?" Applied Economics, Vol. 37, No. 17, pp. 2001-2008.

Mikelarena, F. (1993), "Los movimientos migratorios en España entre 1877 y 1930." Cuadernos Aragoneses de Economía, Vol. 3, No. 2, pp. 213-240.

OECD (2008), Growing Unequal? Income Distribution and Poverty in OECD Countries, OECD, Paris, http://www.oecd.org/dataoecd/45/42/41527936.pdf, p. 77.

O'Farrell, R. (2010), "Wages in the Crisis." Working Paper 2010.03, ETUI (European Trade Union Institute), Brussels.

O'Rourke, K., Williamson, J. G. (1999), Globalization and History. The Evolution of a Nineteenth Century Atlantic Economy. Cambridge, Mass.: MIT Press.

Phillips, K. R. (1992), "Regional Wage Divergence and National Wage Inequality." Economic and Financial Policy Review, Federal Reserve Bank of Dallas, Issue Q IV, pp. 31-44.

Reis, J. (2002), "Human Capital and Industrialization: the Case of a Latecomer (Lisbon 1890)", Session 32: Technology and Human Capital in Historical Perspective, XIII International Economic History Association Congress, Buenos Aires.

Roman, M., Goschin, Z. (2012), "Romanian Immigrants Worldwide: What Makes them Return Home?" Journal of Identity and Migration Studies, Vol. 6, No. 2, pp. 2-17.

Romanian Chamber of Commerce and Industry (2012), Companies with Foreign Participation to Capital, available at: http://www.onrc.ro/statistici/is_ianuarie_2002.pdf.

Romanian Institute of National Statistics, TEMPO online database, available at: https://statistici. insse.ro/shop/.

Roses, J. R. (1998), "Measuring the Contribution of Human Capital to the Development of the Catalan Factory System (1830-61)." European Review of Economic History, Vol. 2, No. 1, pp. 25-48.

Rosés, J. R., Sánchez-Alonso, B. (2002), "Regional Wage Convergence in Spain 1850-1930." Working Paper 02-53, Economic History and Institutions Series 01, Universidad Carlos III de Madrid.

Reher, D. S. (2001), "In Search of the 'Urban Penalty': Exploring Urban and Rural Mortality Patterns in Spain during the Demographic Transition." International Journal of Population Geography, Vol. 7, No. 2, pp. 105-127.

Skoufias, E. (2003), "The Structure of Wages during the Economic Transition in Romania." Economic Systems, Vol. 27, No. 4, pp. 345-366.

Simpson, J. (2000), "Labour Markets and Rural Unrest in Spanish Agriculture, 1860-1936." Working Paper 00-74, Universidad Carlos III de Madrid.

Williamson, J. G. (1998), "Real Wages and Relative Factor Prices in the Third World 1820-1940: Asia." Discussion Paper No. 1844, Harvard Institute of Economic Research.

Williamson, J. G. (1990), Coping with City Growth during the British Industrial Revolution. Cambridge: Cambridge University Press.

Williamson, J. G. (1996), "Globalization, Convergence and History." Journal of Economic History, Vol. 56, No. 3, pp. 1-30.

Wodon, Q. T., Yitzhaki, S. (2005), "Convergence forward and backward?" Available at http://ssrn.com/ abstract $=875531$. 